\title{
THE REVIEW OF ECONOMIC LEGISLATION IN DECEMBER 2013
}

\author{
I.Tolmacheva, Yu.Grunina
}

Late in December and in January, the following amendments were introduced in the legislation: the specifics of the legal status and activities of nongovernment pension funds in the form of joint-stock companies were determined; the list of non-profit organizations which do not need to secure a permit to include in their name the official name - the Russian Federation or Russia - was expanded; amendments as regards public utilities infrastructure and other facilities of public utilities were introduced into a standard concession agreement.

\section{Federal Laws of the Russian Federation}

1. Federal Law No.410-FZ of December 28, 2013 on AMENDMENT OF THE FEDERAL LAW ON NONGOVERNMENT PENSION FUNDS AND INDIVIDUAL STATUTORY ACTS OF THE RUSSIAN FEDERATION

It is established by the law that from January 1 , 2014 new nongovernment pension funds will established only in the form of joint-stock companies.

Due to the above, the law sets the specifics both of reorganization of a non-profit pension fund into a joint-stock pension fund, as well as reorganization (liquidation) of joint-stock pension funds.

Additional requirements have been set to the articles of incorporation, state registration, as well as activities of such a fund (for example, a decision on state registration of the pension fund and amendment of the data on the pension fund in the Unified State Register of Legal Entities is taken by the Central Bank of Russia and a ban on bill operations by a pension fund is introduced).

Simultaneously, changes into requirements set to the officials of a pension fund were introduced. In particular, it is established a manager of the executive body of a pension fund should have at least a two-year experience of work at executive positions at credit institutions or non-credit financial institutions and meet qualifying requirements set by the Central Bank of Russia (as regards non-profit pension funds minimum three-year experience of work at funds, insurance companies or other financial institutions is required). Candidates to the members of the board of directors (supervisory council) should comply with such requirements to a business repute as are set by the Law and approved by the Central bank of Russia. Within a month from the day of receipt of an application, the Central Bank of Russia takes a decision and informs the applicant of its consent on appointment (election) of the person specified in the application to that position or sends the applicant a reasonable refusal in writing to grant such a consent. The above refusal can be appealed against in accordance with the procedure set by the legislation of the Russian Federation.

The conceptual frameworks including early nongovernment pension security whose mandatory condition is payment of a nongovernment pension before the age of retirement due to employment at jobs with hazardous and (or) dangerous labor conditions were specified.

2. Federal law No. 413-FZ of December 28, 2013 on AMENDMENT OF ARTICLE 4 OF THE FEDERAL LAW ON NON-PROFIT ORGANIZATIONS AND ARTICLE 6.1 OF FEDERAL LAW ON AUTONOMOUS INSTITUTIONS.

According to the amendments into the legislation, it is established that the official name - the Russian Federation and Russia - as well as derivatives from those words can be used without permission issued in accordance with the procedure set by the Government of the Russian Federation in the names of the following institutions:

- centralized religious organizations whose entities have operated on a legal basis in the territory of the Russian Federation for at least fifty years as of the date of application of such an organization for state registration;

- non-profit organizations established on the basis of federal laws, as well as in accordance with the Acts of the President of the Russian Federation and the Government of the Russian Federation;

- all-Russian nongovernment organizations;

- structural units of all-Russian nongovernment associations in case of utilization in the names of the above structural units of the full name of such a nongovernment association;

- non-profit organizations whose sole founder is a legal entity established on the basis of Acts of the President of the Russian Federation and the Government of the Russian Federation or a legal entity which uses in its name the official name - the Russian Federation or Russia - as well as derivatives of the above words by vir- 
tue of the law or in accordance with a permission secured in conformity with the procedure established by the Government of the Russian Federation in case of use in the names of the above non-profit organizations of a full name of their founder-legal entity.

Also, the grounds for termination of the right to use in the names of non-profit organizations of the official name - the Russian Federation and Russia - as well as derivatives of the above words have been specified:

- withdrawal of a permit;

- termination of the right of a legal entity - the sole founder of a non-profit organization - to use in its name the official name - the Russian Federation or Russia - as well as derivatives of the above words.

In case of termination of the right to use in the name of a non-profit organization of the official name - the Russian Federation or Russia - as well as derivatives of the above words, the non-profit organization is obligated to introduce relevant amendments in its founding documents within three months from the date of termination of the right to use in its name the official name - the Russian Federation or Russia.

\section{Resolutions of the Government of the Russian Federation}

Resolution No. 37 of January 18, 2014 on INTRODUCTION IN A STANDARD CONCESSION AGREEMENT OF AMENDMENTS AS REGARDS THE SYSTEM OF PUBLIC UTILITIES INFRASTRUCTURE AND OTHER FACILITIES OF PUBLIC UTILITIES, INCLUDING WATER-SUPPLY, HEATSUPPLY, GAS-SUPPLY AND POWER-SUPPLY UNITS, WATER REMOVAL PLANTS, SEWAGE TREATMENT PLANTS, RECYCLING AND UTILIZATION (BURIAL) DOMESTIC
WASTE, FACILITIES MEANT FOR LIGHTING OF TERRITORIES OF URBAN AND RURAL SETTLEMENTS, LANDSCAPING FACILITIES, AS WELL AS SOCIAL AMENITIES

A standard concession agreement as regards the system of public utilities infrastructure and other facilities of public utilities (approved by Resolution No.748 of December 5, 2006 of the Government of the Russian Federation) is supplemented with provisions under which:

- a concessioner is to achieve the planned performances in its activities;

- the maximum amount of expenditures - which are made by a concessioner during the entire period of the agreement - on establishment or modernization of the project specified in the agreement is to be stated;

- a procedure is to be established for indemnification of such expenditures of the concessioner as are to be compensated in accordance with statutory acts regulating the sphere of heatsupply, water-supply and water removal and not indemnified to the concessioner as of the date of expiry of the agreement;

- setting, changing and adjustment of regulated prices (tariffs) on goods (fulfilled jobs and rendered services) produced and realized by a concessioner are carried out in accordance with rules which are effective as of the date the agreement was concluded (by agreement between the parties and by approval by the tariffs regulating authority in accordance with the procedure established by the Government of the Russian Federation, setting and changing of tariffs is carried out in conformity with the rules which are effective as of the date of such setting and changing of tariffs). 